227. 医療情報管理システムの運用経験について

オリオノ和泉病院放射線科 ○前田一美川上匡平

(目的) 我々は第 44 回総会学術発表において、医療デー夕の管理と伝送に関する試みとして 医療情報管理システムの構筑について発表した。今回それらシステムを槚診用医療情報管理シス テムとして運用することにより、画像登録や検索などについて若干の経験を得たのて報告する。

（方法）人間ドック受診により発生する医療情報、胸・腹部 X 線、上部消化管撮影を C R り o n-1 i n e で登録、その他の画像、腹部エコー、M R I 、X 線 C T や文章類などは C C D スキャナで読み取り、それらを一括して高容量の記録媒体（光ティスク）に経年的に記録・管理 することにした。

(結果) 個人の医療情報をテジタル化と共に、一枚の記録媒体汇経年的に記録、多年に亘って 管理することにより各個人の病状の経時的变化の観察が至便であり、検索時間などの省力化が可 能になると思われる。

228. パソコンLAN（L○cal Area Nework）を用いた放射線システム（第2 報）

大阪がん予防㛟祅センター O能谷 年起四绮政治 小林秀穆

（目的）現在、パソコンレベルで简易にL ANを棈策し、放射線笛理システムを運用している。今回ワークス テーションの增加により报らデータ目が堌えその资源保存の問題を解消するために、L ANの搪镸接繶を行った。

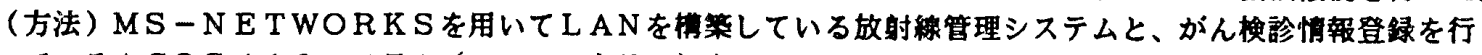
っているACOS 410 システム（ミニコンクラス）を、Branch4670（伝送媒体）で接続する。

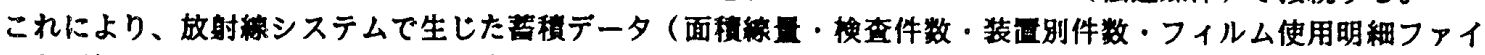
ルなど）をACOSにアクセスする事によりテータ保存を容易に行っていく。 又各ワークステーションより

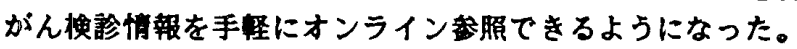

(結果)システム间接紿を行うことでデータの有効利用を行え、また资源活用がでた。

\title{
229. 故射檄科情報管理システムの開発
}

（株）島津製作所 医用技街部 ○後藤宜久 柴田幸一

パーソナルコンビュータを用いた放射楾科情報管理システムを開発した。診断用X楾装面と直粘して撮影データヘ

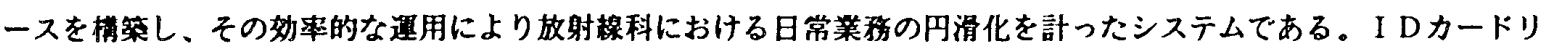
一タによる总者基本情報入力と、X楾装蒖から撮影条件、フィルム情報などのオンライン収集を行ない、照射録の作 成、フィルム管理、被爆楾量管理、各種桡計表などの帳票作成業務のコンビュー夕処理化を行なうもので、日常業弱 における所要時间の短綰、作羓内容の票準化が推進できる、本システムは、患者基本情報の影影フィルムへのプリン ト機能などの特長を有し、椱数台でネットワークを楧成して、赫合型システムとしてクレードアップできるシステム である。

230. 放射線部サフシステム 第3 報（RIインビボシステム）

名大病院 ○青山裕一 三兒厚 山下浩 安部暂太郎 西野正成 野口英三山口宏

（目的）予約オーダ等の複誰なRIインヒホ関連業務を、大型コンヒュータの支援を背景に合理化・効 事化し、効果的な医療を提供することを目的とした。

（方法）現犾の業勜形態を踏まえて、合理化・効标化を図るシステム設計を行った。その主な項目は

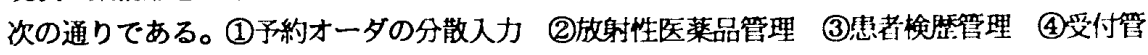
理・結果入力。

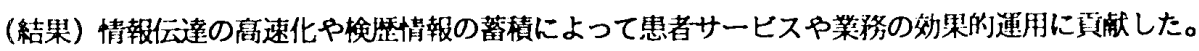

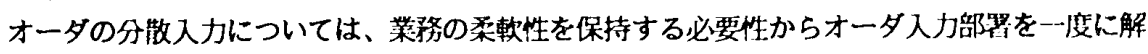
放せす、㕻次拉大していく方法を計画準備している。 